\title{
Pembagian Harta Warisan Dalam Tradisi Masyarakat Sasak : Studi Pada Masyarakat Jago Lombok Tengah
}

\author{
Syahdan \\ STIT Palapa Nusantara Lombok NTB \\ E-mail:syahdankbr@ymail.com \\ HP:081803648316
}

\begin{abstract}
Abstrak
Masyarakat Sasak mempunyai cara tersendiri dalam menyelesaikan masalah yang berkaitan dengan harta seseorang yang meninggal dunia dengan anggota keluarga yang ditinggalkannya. Walaupun mayoritas beragama Islam, pembagian harta warisan berdasarkan ilmu faraidh sama sekali tidak diterapkan. Yang digunakan adalah sistem mayorat laki-laki, yaitu anak laki-laki sulung (atau keturunan laki-laki) merupakan ahli waris tunggal. Anak laki-laki tertua yang sudah dewasa bisa secara perorangan, ia berkedudukan sebagai pemegang mandat orang tua yang mempunyai kewajiban mengurus anggota keluarga yang lain yang ditinggalkan termasuk harta warisan. Metode yang digunakan dalam penelitian ini yaitu; (1) metode observasi, (2) metode wawancara, dan (3) metode dokumentasi. Penelitian ini sendiri menggunakan pendekatan normatif-sosiologis. Pendekatan normatif dimaksudkan untuk menelusuri alasan yang dipakai dalam pelaksanaan sistem kewarisan adat berdasarkan norma-norma hukum yang berlaku, sedangkan sosiologis untuk melihat realitas kehidupan masyarakat Desa Jago dalam melaksanakan sistem kewarisan tersebut. Hasil yang diperoleh adalah: Pertama, karena menganut sistem mayorat laki-laki, secara otomatis seluruh harta warisan jatuh kepada anak tertua laki-laki, hanya saja pada harta tertentu seperti tanah, tetap diadakan pembagian kepada ahli waris lainnya. Hal ini bertujuan untuk memberikan bekal bagi ahli waris tersebut. Kedua, Sistem dan praktek pembagian harta warisan tersebut tidak sesuai dengan farâ'id. Namun berdasarkan tasâlub hal ini dibolehkan karena sesuai dengan konsep pembentukan hukum Islam yaitu terwujudnya kemaslahatan ummat.
\end{abstract}

Kata kunci/Key word : Tradisi, Harta Waris. 
Syahdan | Pembagian Harta Warisan Dalam Tradisi Masyarakat Sasak : Studi Pada Masyarakat Jago Lombok Tengah

\section{A. PENDAHULUAN}

Oleh umat Islam al-Qur'an merupakan kitab Allah yang diturunkan kepada Nabi Muhammad SAW, yang berisi norma-norma masyarakat yang mencakup seluruh aspek kehidupan manusia. Norma tersebut mengandung sistematika dalam suatu totalitas, sehingga saling berhubungan secara fungsional dalam rangka mengarahkan manusia kepada pembentukan diri menjadi manusia yang sempurna.

Masalah kewarisan menduduki tempat amat penting dalam hukum Islam. Ayat al-Qur'an mengatur hukum kewarisan dengan jelas dan terperinci. Hal ini dapat dimengerti sebab masalah warisan pasti dialami oleh setiap orang. Kecuali itu, hukum kewarisan langsung menyangkut harta benda yang apabila tidak diberikan ketentuan pasti amat mudah menimbulkan sengketa di antara ahli waris. Setiap terjadi peristiwa kematian seseorang, segera timbul bagaimana harta peninggalannya harus diberlakukan dan kepada siapa saja harta itu dipindahkan, serta bagaimana caranya. Inilah yang diatur dalam hukum waris. (Basyir, 2000: 03).

Dalam sejarah perjalanan hukum Islam di Indonesia sejak zaman pemerintahan Hindia Belanda sampai sekarang telah melahirkan beberapa titik singgung, selanjutnya titik singgung tersebut dikedepankan sebagai teori yang berkaitan dengan realita yang dihadapi oleh hukum Islam. Ketika hukum Islam hendak menanamkan nilai-nilainya sebagai landasan kesadaran hukum yang mengatur tata tertib masyarakat, ketika itu pula ia berhadapan dengan nilai-nilai kesadaran hukum adat. Sejauh mana kadar kekuatan kesadaran nilai-nilai hukum adat terhadap penerimaan nilai-nilai hukum Islam, ternyata berdampak terjadinya ragam pendapat yang berlanjut dengan berbagai corak teori, lahirlah teori-teori titik singgung hukum adat dan Islam, terutama di bidang perdata, termasuk hukum kewarisan. (Harahap, dalam Saimima, 1988: 125).

Hukum kewarisan adat di Indonesia sangat dipengaruhi oleh prinsip garis keturunan yang berlaku pada masyarakat yang bersangkutan, yang mungkin merupakan patrilineal murni, patrilineal beralih-alih (alternerend) matrilineal ataupun bilateral (walaupun sukar ditegaskan dimana berlakunya di Indonesia), ada pula prinsip unilateral berganda 
Syahdan | Pembagian Harta Warisan Dalam Tradisi Masyarakat Sasak : Studi Pada Masyarakat Jago Lombok Tengah

atau (dubbel-unilateral). Prinsip-prinsip garis keturunan terutama berpengaruh terhadap penetapan ahli waris maupun bagian harta peninggalan yang diwariskan (baik yang materiel maupun immaterial (Soekanto, 2002: 259.)

Hukum kewarisan adat adalah hukum adat yang memuat garis-garis ketentuan tentang sistem dan azas-azas hukum kewarisan, tentang harta warisan, pewaris dan ahli waris serta cara bagaimana harta warisan itu dialihkan penguasaan dan pemilikannya dari pewaris kepada waris. Hukum kewarisan adat sesungguhnya adalah hukum penerusan harta kekayaan dari suatu generasi kepada keturunannya. (Hadikusuma, 2003: 07).

Masyarakat Desa Jago Kecamatan praya Kabupaten Lombok Tengah, mempunyai cara tersendiri dalam menyelesaikan hubungan hukum yang ditimbulkan berkaitan dengan harta seseorang yang meninggal dunia dengan anggota keluarga yang ditinggalkannya. Masyarakat adat desa Jago sebagian menganut sistem mayorat laki-laki, yaitu apabila anak laki-laki tertua pada saat pewaris meninggal atau anak laki-laki sulung (atau keturunan laki-laki) merupakan ahli waris tunggal. (Soekanto, 2002: 260).

Anak laki-laki tertua sebagai pengganti orang tua yang telah meninggal dunia bukanlah pemilik harta peninggalan secara perorangan, ia berkedudukan sebagai pemegang mandat orang tua yang mempunyai kewajiban mengurus anggota keluarga yang lain yang ditinggalkan, termasuk mengurus ibu apabila ayah yang meninggal dan begitu juga sebaliknya, berkewajiban mengurus ayah apabila ibu yang meninggal.

Keistimewaan lain dari anak laki-laki tertua di kalangan masyarakat adat Desa Jago Kecamatan Praya, sejak anak laki-laki tersebut masih kecil, harta benda baik yang berupa rumah, ladang dan perabotan rumah tangga yang diwarisi secara turun temurun sudah diatasnamakan kepada anak laki-laki tertua tersebut. Jadi selain proses pewarisan yang dilakukan setelah pewaris wafat, dalam masyarakat adat Desa Jago Kecamatan Praya, proses pewarisannya banyak juga dilakukan sebelum pewaris wafat walaupun proses pewarisan tersebut hanyalah sebatas pada pengatas namaan secara lisan terhadap barang-barang tertentu kepada anak laki-laki tertua, namun dapat dipastikan barangbarang tersebut sudah akan diwariskan kepadanya secara keseluruhan. 
Syahdan | Pembagian Harta Warisan Dalam Tradisi Masyarakat Sasak : Studi Pada Masyarakat Jago Lombok Tengah

Kelemahan dan kebaikan sistem kewarisan mayorat terletak pada kepemimpinan anak tertua dalam kedudukannya sebagai pengganti orang tua yang telah wafat dalam mengurus harta kekayaan dan memanfaatkannya guna kepentingan semua anggota keluarga yang ditinggalkan. Anak tertua yang penuh tanggung jawab akan dapat mempertahankan keutuhan dan kerukunan keluarga sampai semua waris menjadi dewasa dan dapat berdiri sendiri mengatur rumah tangga sendiri. Tetapi anak tertua yang tidak bertanggung jawab, yang tidak dapat mengendalikan diri terhadap kebendaan, yang pemboros dan lain sebagainya jangankan akan dapat mengurus harta peninggalan dan saudara-saudaranya malahan sebaliknya ia yang diurus oleh anggota keluarga yang lain.

Sistem mayorat seringkali disalah tafsirkan tidak saja oleh orang yang tidak memahaminya,tetapi juga oleh pihak waris anak tertua itu sendiri. Anak tertua sebagai pengganti orang tua yang telah meninggal bukanlah pemilik harta peninggalan secara perseorangan, ia hanya berkedudukan sebagai penguasa, sebagai pemegang mandat orang tua yang dibatasi oleh musyawarah keluarga, dibatasi oleh kewajiban mengurus anggota keluarga lain yang ditinggalkan, tidak semata-mata berdasarkan harta peninggalan tetapi juga berdasarkan asas tolong menolong oleh bersama untuk bersama. (Hadikusuma, 2930). Dari fenomena dan di atas, kiranya sangat perlu untuk diangkat, dikaji secara konfrehensif.

\section{B. TELAAH PUSTAKA}

\section{Hukum Islam}

Menurut Amin Syarifuddin, untuk memahami hukum Islam, perlu diketahui terlebih dahulu kata "Hukum"dalam bahasa Indonesia dan kata hukum itu disandarkan pada kata "Islam" .Pengertian Hukum secara sederhana adalah "seperangkat peraturan tentang tingkah laku manusia yang di akui oleh sekelompok masyarakat itu, berlaku dan mengikat bagi seluruh anggotanya."bila kata hukum ini disandarkan pada kata Islam atau syara', maka hukum Islam berarti "seperangkat peraturan berdasarkan wahyu Allah dan sunah nabi tentang tingkah laku manusia mukallaf yang diakui dan di yakini mengikat bagi seluruh manusia yang beragama Islam.

Volume 4 Nomor 2 (2016) November $\mid \mathscr{P} \mathcal{A} \mathcal{L} \mathcal{A} \mathcal{P} A$ : Jurnal Studi Keislaman 
Syahdan | Pembagian Harta Warisan Dalam Tradisi Masyarakat Sasak : Studi Pada Masyarakat Jago Lombok Tengah

Konsepsi hukum dalam ajaran Islam berbeda dengan konsepsi hukum pada umumnya, khususnya hukum modern. Dalam Islam hukum dipandang sebagai bagian dari ajaran agama.dan norma-norma hukum bersumber pada agama umat islam meyakini bahwa hukum islam berdasarkan kepada wahyu ilahi.oleh karena itu, ia disebut syariah.(Anwar, 2007:3). Maka adapun yang dimaksud dengan hukum Islam adalah praturan-peraturan dan ketentuan-ketentuan yang berkenaan dengan kehidupan yang berdasarkan Qur'an dan sunnah.

\section{Penjenjangan Norma-norma Islam}

Ahli-ahli hukum Islam klasik membuat penjenjangan norma hukum Islam kedalam dua tingkatan, yaitu: al-ushul (asas-asas umum) dan al-furu'(peraturan-peraturan hukum konkrit). Al-ushul, tingkatan ini meliputi kategori yang luas sehingga mencakup juga norma-norma filosofis dasar yang menjadi tempat tegaknya norma-norma tsb. dan al-furu' adalah konkretisasi dari asas umum dan terwujud baik dalam ketentuan hokumhukum taklifi seperti,halal, haram, sunat, makruh dan mubah (Anwar, 2007:12-13).

\section{Sumber-Sumber Hukum Islam}

Kata-kata sumber dalam hukum Islam merupakan terjemah dari kata mashadir yang berarti wadah ditemukannya dan ditimbanya norma hukum. Sumber hukum Islam yang utama adalah Al-Qur'an dan sunah. Selain menggunakan kata sumber, juga digunakan kata dalil yang berarti keterangan yang dijadikan bukti atau alasan suatu kebenaran. Selain itu, ijtihad, ijma', dan qiyas juga merupakan sumber hukum karena sebagai alat bantu untuk sampai kepada hukum-hukum yang dikandung oleh Al-Qur'an dan sunah Rasulullah SAW. Hal ini sejalan dengan firman Allah SWT dalam surat al Hasyr ayat: 7 yang artinya: apa yang diberikan Rasul kepadamu maka terimalah dia, dan apa yang dilarangnya bagimu maka tinggalkanlah.

Hadits sebagai perkataan, perbuatan dan taqrir Nabi SAW merupakan sumber hukum Islam yang kedua memilki fungsi; memperkuat hukum-hukum yang telah ditentukan oleh al Qur'an, sehingga kedunya menjadi sumber hukum untuk satu hal 
Syahdan | Pembagian Harta Warisan Dalam Tradisi Masyarakat Sasak : Studi Pada Masyarakat Jago Lombok Tengah

yang sama. Selanjutnya berfungsi memberikan rincian dan penjelasan terhadap ayat-ayat Al-Qur'an yang masih bersifat umum. Ayat al-Qur'an memerintahkan shalat, membayar zakat, dan menunaikan ibadah haji, semuanya bersifat garis besar, tidak menjelaskan jumlah rakaat dan bagaimana cara melaksanakan shalat, tidak merinci batas mulai wajib zakat, tidak memarkan cara-cara melaksanakan haji, kesemuanya ini dijelaskan oleh hadits.

Sumber Hukum Islam yang ketiga adalah ijtihad. Ijtihad menurut istilah ialah berusaha dengan sungguh-sungguh untuk memecahkan suatu masalah yang tidak ada ketetapannya, baik dalam Al-Qur'an maupun Hadits, dengan menggunkan akal pikiran yang sehat dan jernih, serta berpedoman kepada cara-cara menetapkan hukumhukumyang telah ditentukan. Hasil ijtihad dapat dijadikan sumber hukum yang ketiga. Untuk melakukan ijtihad (mujtahid) harus memenuhi bebrapa syarat yakni, sebagai mujtabid wajib memiliki kemampuan yang luas tentang Al-Qur'an dan Hadits, terutama yang bersangkutan dengan hokum, memahami bahasa Arab dengan segala kelengkapannya, mengetahui soal-soal ïma, menguasai ilmu ushul fiqih dan kaidahkaidah fiqih yang luas.

Selain 'jma' para ulama' juga menggunakan metode qiyas dalam menggali hokum. Qiyas (analogi) adalah menghubungkan suatu kejadian yang tidak ada hukumnya dengan kejadian lain yang sudah ada hukumnya karena antara keduanya terdapat persamaan illat atau sebab-sebabnya. Contohnya, mengharamkan minuman keras, seperti bir dan wiski. Haramnya minuman keras ini diqiyaskan dengan khamar yang disebut dalam Al-Qur'an karena antara keduanya terdapat persamaan illat (alasan), yaitu sama-sama memabukkan. Jadi, walaupun bir tidak ada ketetapan hukumnya dalam Al-Qur'an atau Hadits tetap diharamkan karena mengandung persamaan dengan khamar yang ada hukumnya dalam Al Qur'an.

\section{Pengertian Warits}

Warisan atau kewarisan yang sudah populer dalam bahasa Indonesia berasal dari bahasa Arab yaitu : ورثـ- يرث- ورثا- وارثة yang berarti pindahnya harta si Fulan 
Syahdan | Pembagian Harta Warisan Dalam Tradisi Masyarakat Sasak : Studi Pada Masyarakat Jago Lombok Tengah

(mempusakai harta si Fulan). (Mahmud Yunus,1989:496) Bisa juga diartikan dengan mengganti kedudukan, seperti firman Allah SWT : وورث سليمان داود, artinya Sulaiman menggantikan kedudukan Daud.

Dalam kitab-kitab fikih, warisan lebih sering disebut dengan farâid (فرائض) mufradnya (فريضة) yang berarti ketentuan. Pengertian ini didasarkan atas firman Allah SWT وقد فرضتم لهن فريضة فنصف ما فرضتم: Al-Baqarah : 237). Kata “warisan” yang asal katanya adalah.. waratsa. adalah salah satu cabang ilmu Islam yang membahas masalah pembagian harta benda setelah yang mempunyai harta benda itu meninngal dunia. Sedangkan menurut kompilasi hukum Islam adalah: hukum yang mengatur tentang pemindahan hak pemilikan harta peninggalan(tirkah) pewaris, siapa yang berhak menjadi ahli waris dan bagian masing-masing ahli waris itu sendiri (Daradjat, 1995: 2). Sedangkan yang dimaksud dengan pewaris dalam hukum kewarisan adalah orang yang pada saat meninggalnya atau dinyatakan telah meninggal berdasarkan pengadilan ia beragama Islam yang meninggalkan ahli waris dan harta warisan.

Menurut Hazairin sebagaimana ditulis oleh Hadikusuma (1995:56) bahwa hukum waris adat mempunyai corak tersendiri dari alam pikiran masyarakat yang tradisional dengan bentuk kekerabatan yang sistem keturunannya patrilineal, matrilineal, parental atau liberal.

\section{Sebab-sebab Terjadinya Kewarisan}

Hal-hal yang menyebabkan seseorang berhak mewaris menurut Ali ashShabuniy, (1995:55) adalah : (1) Kekerabatan sesungguhnya, yakni hubungan nasab. Yaitu ibu, bapak, anak-anak, saudara-saudara, para paman dan lain-lain. Ringkasnya adalah : orang tua, anak dan orang-orang yang bernasab dengan mereka. Firman Allah SWT QS Al-Anfal Ayat 8. (2). Pernikahan, yaitu akad nikah yang syah yang terjadi di antara suami isteri, sekalipun sesudah pernikahan belum terjadi persetubuhan atau berduaan di tempat sunyi (khalwat). Mengenai nikah fasid atau nikah batal, tidak bisa 
Syahdan | Pembagian Harta Warisan Dalam Tradisi Masyarakat Sasak : Studi Pada Masyarakat Jago Lombok Tengah

menyebabkan hak waris. Firman Allah SWT QS. An-Nisa':12. (3) Perbudakan, yaitu hubungan bekas budak dengan orang yang memerdekakannya. Apabila bekas budak itu tidak mempunyai ahli waris yang berhak menghabiskan hartanya.. (4) Tujuan Islam (Jihâtul al-Islâm), yaitu bagi orang yang tidak mempunyai ahli waris maka hartanya ditaruh di Baitul Mal untuk kepentingan orang Islam. Menurut fuqaha Hanafiah, Hanabilah, dan ketentuan yang terdapat dalam undang-undang Mesir bahwa kas perbendaharaan negara mendapat harta yang tak terwariskan itu dengan jalan bukan mempusakai, tetapi dengan anggapan bahwa ia adalah lembaga untuk menyalurkan kemaslahatan umat Islam. Sementara menurut fuqaha Syafi'iyah, Baitul Mal mendapat harta yang tak terwariskan itu dengan jalan mempusakai melalui usubah atau atas nama Islam.

\section{Rukun-rukun Kewarisan}

Rukun kewarisan adalah (1) Muwarris (orang yang memberi warisan), yakni mayat dimana orang lain berhak mewarisi dari padanya akan apa saja yang ditinggalkan sesudah matinya. (2) Wâris (penerima warisan), yakni orang yang berhak mewarisi dengan sebab yang telah dijelaskan, seperti : kekerabatan, pernasaban, perkawinan dan sebagainya. (3) Maurûs (benda yang diwariskan), yaitu sesuatu yang ditinggalkan mayat, seperti : harta, kebun dan sebagainya. Maurûs| ini juga disebut irs|un, turâs|un dan murâs|un yang kesemuanya merupakan sebutan untuk segala sesuatu yang ditinggalkan mayat ahli waris.

\section{Syarat-syarat Kewarisan}

Adapun syarat-syarat kewarisan ada tiga yaitu: (1) Meninggalnya pewaris yang dimaksud dengan meninggalnya pewaris baik secara hakiki ataupun secara hukmiy ialah bahwa seseorang telah meninggal dan diketahui oleh ahli warisnya atau sebagian dari mereka, atau vonis yang ditetapkan hakim terhadap seseorang yang tidak diketahui lagi keberadaanya. Sebagai contoh orang yang hilang yang keadaannya tidak diketahui lagi secara pasti, sehingga hakim memvonisnya sebagai orang yang telah meninggal. Hal ini harus diketahui secara pasti, karena bagaimanapun keadaannya manusia yang masih 
Syahdan | Pembagian Harta Warisan Dalam Tradisi Masyarakat Sasak : Studi Pada Masyarakat Jago Lombok Tengah

hidup tetap dianggap mampu untuk mengendalikan seluruh hartanya. Hak kepemilikannya tidak dapat diganggu gugat oleh siapapun kecuali setelah ia meninggal.

Kemudian yang yang ke- (2) adalah masih hidupnya para ahli waris. Maksudnya, pemindahan hak kepemilikan dari pewaris harus kepada ahli waris yang secara syari'at benar-benar masih hidup sebab orang yang sudah mati tidak memiliki hak untuk mewarisi. (3) Diketahuinya posisi ahli waris. Dalam hal ini posisi para ahli waris hendaklah diketahui secara pasti, misalnya suami, isteri dan sebagainya. Sehingga pembagi mengetahui masing-masing ahli waris. Sebab dalam hukum kewarisan perbedaan jauh dekatnya kekerabatan akan membedakan jumlah yang diterima, tidak cukup hanya mengatakan bahwa seseorang adalah saudara sang pewaris, akan tetapi harus dijelaskan apakah ia saudara kandung, seayah atau seibu. Masing-masing ada yang berhak menerima warisan karena sebagai z|awî al-furûd, ada yang 'asabah, ada yang terhalang tidak mendapatkan warisan (mabjûb).

\section{Penghalang Kewarisan}

Yang menjadi penghalang dalam kewarisan ada empat, yaitu (1) Perbudakan, seorang yang berstatus sebagai budak tidak mempunyai hak untuk mewarisi dari saudaranya sendiri, sebab segala sesuatu yang dimiliki budak secara langsung menjadi hak milik tuannya. Hal ini sesuai dengan firman Allah SWT. QS an Nahl ayat 75). Menurut Idris Ramulyo, perbudakan menjadi penghalang mewarisi bukanlah karena status sosialnya, melainkan karena formalnya sebagai hamba sahaya dipandang tidak cakap menguasai harta benda. (Ramulyo,1994:110). (2) Pembunuhan, pembunuhan terhadap pewaris oleh ahli waris menyebabkan tidak dapat mewarisi harta yang ditinggal oleh orang yang dibunuh meskipun yang dibunuh tidak meninggalkan ahli waris lain selain yang dibunuh. (3) Berlainan agama, keadaan berlainan agama menghalangi memperoleh harta warisan. Dalam hal ini yang dimaksud ialah antara ahli waris dengan muwarris berbeda agama

Dalam urusan dunia dan akherat hubungan antara dua kerabat yang tidak seagama hanya sebatas dalam hal-hal berbuat baik saja dalam pergaulan dunia dan tidak 
Syahdan | Pembagian Harta Warisan Dalam Tradisi Masyarakat Sasak : Studi Pada Masyarakat Jago Lombok Tengah

menyangkut soal agama. Hak kewarisan merupakan soal agama karena ketentuan pelaksanaannya atas kehendak Allah SWT. (4) Berlainan negara, ditinjau dari segi agama orang yang mewariskan dan orang yang mewarisi, berlainan negara diklasifikasikan menjadi dua yaitu berlainan negara antar orang-orang non muslim dan berlainan negara antar orang Islam.

Menurut Abu Hanifah dan sebagian ulama Hanabilah sebagaimana dikutip Fatchur Rahman dalam bukunya Ilmu Waris, bahwa berlainan negara antar orang-orang non muslim menjadi penghalang saling mewarisi diantara mereka, karena terputusnya is \}mah dan tidak adanya hubungan perwalian. Memberikan pusaka kepada ahli waris yang berbeda negaranya dengan negara muwarris berarti memberikan harta pusaka kepada musuhnya atau musuh keluarganya.

Berlainan negara antar orang Islam tidak menjadi penghalang untuk saling mewarisi. Sebab negara-negara Islam itu dianggap sebagai negara kesatuan. Hubungan kekuasaan ('is $\}$ mah) antar negara-negara tersebut tidak putus, bahkan terjalin rasa solidaritas antar warga negaranya satu sama lain. Lebih jauh dari itu bahwa negara-negara tersebut menjalankan fungsi yang sama yaitu hukum Islam, walaupun tiap-tiap negara itu mempunyai perbedaan mengenai bentuk kenegaraannya, sistem pemerintahannya, politik yang dianutnya, peraturan-peraturan yang dijalankan dan sebagainya.

\section{PEMBAHASAN}

\section{Sistem Kewarisan Masyarakat Desa Jago}

Masyarakat bangsa Indonesia yang menganut berbagai macam agama dan berbagai macam kepercayaan yang berbeda mempunyai bentuk-bentuk kekerabatan dengan sistem keturunan yang berbeda-beda pula. Sistem keturunan itu sudah berlaku sejak dahulu kala sebelum masuknya ajaran agama Hindu, Islam dan Kristen. Sistem keturunan yang berbeda-beda ini nampak pengaruhnya dalam sistem kewarisan hukum adat.

Secara teoritis sistem keturunan dapat dibedakan dalam tiga corak yaitu : Pertama sistem Patrilineal yaitu sistem keturunan yang ditarik menurut garis bapak, 
Syahdan | Pembagian Harta Warisan Dalam Tradisi Masyarakat Sasak : Studi Pada Masyarakat Jago Lombok Tengah

dimana kedudukan pria lebih menonjol pengaruhnya dari kedudukan wanita di dalam pewarisan (Gayo, Alas, Batak, Nias, Lampung, Buru, Seram, Nusa Tenggara dan Irian). Kedua, sistem Matrilineal yaitu sistem keturunan yang ditarik menurut garis ibu, dimana kedudukan wanita lebih menonjol pengaruhnya daripada kedudukan pria di dalam pewarisan (Minangkabau, Enggano, Timor). Ketiga adalah sistem parental atau bilateral yaitu sistem keturunan yang ditarik menurut garis orang tua, atau menurut garis dua sisi (bapak-ibu) dimana kedudukan pria dan wanita tidak dibedakan di dalam pewarisan, dalam hal ini terjadi seperti di Aceh, Sumatera Timur, Riau, Jawa, Kalimantan, Sulawesi dan lain-lain ( Hadikusuma, 2003: 23.)

Sedangkan menurut sistem kewarisan adat, dikenal adanya tiga sistem kewarisan yaitu : Pertama, sistem kewarisan Individual, yang merupakan sistem kewarisan dimana para ahli waris mewarisi perorangan (Batak, Jawa, Sulawesi dan lain-lain). Kedua, sistem kewarisan kolektif, dimana para ahli waris secara kolektif (bersama-sama) mewarisi harta peninggalan yang tidak dapat dibagi-bagi pemilikannya kepada masing-masing ahli waris (Minangkabau). Ketiga adalah sistem kewarisan mayorat. Mayorat laki-laki, yaitu apabila anak laki-laki tertua pada saat pewaris meninggal atau anak laki-laki sulung (atau keturunan laki-laki) merupakan ahli waris tunggal seperti di Lampung. Sedangkan mayorat perempuan, yaitu apabila anak perempuan tertua saat pewaris meninggal, adalah ahli waris tunggal, misalnya pada masyarakat di tanah Semendo. (Soekanto, 2002, 260)

Dari berbagai informan yang dipercaya dari para tokoh agama, tokoh adat, dan tokoh masyarakat, mengemnukakan bahwa yang dimaksud dengan hukum kewarisan itu ialah : peraturan-peraturan mengenai proses berpindahnya harta seseorang baik ia masih hidup maupun telah meninggal untuk diteruskan kepada sanak keluarga atau keturunannya. Masyarakat desa Jago kec.Praya, bahwa sistem kewarisan yang dipakai adalah sebagian besar sistem kewarisan yang sama dengan masyarakat lampung yaitu mayorat laki-laki, dimana kedudukan anak tertua laki-laki sebagai pewaris orang tuanya, hal ini karena masyarakat menganut sistem keturunan patrilineal yang keturunannya ditarik menurut garis bapak dimana peran laki-laki lebih mononjol dari pada perempuan. 
Syahdan | Pembagian Harta Warisan Dalam Tradisi Masyarakat Sasak : Studi Pada Masyarakat Jago Lombok Tengah

Kedudukan anak tertua (sulung) dalam keluarga adalah pemimpin rumah tangga menggantikan ayah atau ibunya sebagai penerus tanggung jawab orang tuanya yang telah wafat. Ia berkewajiban mengurus dan memelihara saudara-saudaranya yang lain terutama tanggung jawab terhadap harta warisan dan kehidupan adik-adiknya yang masih kecil sampai mereka berumah tangga sendiri dalam wadah kekerabatan mereka yang turuntemurun.

Perlu kiranya diperjelas bahwa sistem mayorat yang ada di desa Jago bersifat mutlak terbatas, artinya bahwa harta warisan yang diberikan orang tua kepada anak lakilaki tertua, bukan berarti tidak dapat dibagi sama sekali dengan anggota keluarga yang lain atau adik-adiknya. Terhadap harta-harta tertentu bisa dilakukan pembagian kepada anggota keluarga yang lain (saudara-saudara yang ada di bawahnya) untuk bekal hidup mereka nantinya.

Anak tertua laki-laki (sulung) sebagai pewaris orang tuanya tidaklah segampang dan semudah yang orang bayangkan. Dia harus bisa mengatur harta yang diberikan dengan sebaik-baiknya untuk kepentingan keluarga, konsekuensinya apabila tidak bisa melaksanakan amanat yang dibebankan di pundaknya, maka ia harus rela diambil alih dan diatur oleh para pemangku adat untuk ditetapkan pembagiannya berdasarkan ketentuan adat yang berlaku di desa Jago kec.Praya.

Karena beratnya tugas tersebut anak tertua haruslah seorang laki-laki, misalkan dalam sebuah keluarga anak pertama, kedua dan ketiga adalah perempuan sedangkan anak yang keempat laki-laki (bungsu) tetap anak laki-laki bungsu tersebut didudukkan sebagai anak tertua. Namun demikian apabila dalam sebuah keluarga tidak terdapat anak laki-laki sama sekali melainkan perempuan semua, maka anak pertama perempuan tersebut diumpakan sebagai laki-laki. Sedangkan apabila dalam sebuah keluarga tidak terdapat anak sama sekali yang akan dijadikan ahli waris, maka mereka bisa mengangkat seorang anak secara adat melalui musyawarah adat. Mengenai hal ini Hazairin berkata : Bagi sistem mayorat itu dibutuhkan ialah ketentuan tentang apa caranya melanjutkan hak mayorat itu jika pada saat matinya si pewaris tidak ada baginya seorang anakpun, maka apabila dalam sistem mayorat laki-laki tidak ada sama sekali anak laki-laki, cuma ada anak 
Syahdan | Pembagian Harta Warisan Dalam Tradisi Masyarakat Sasak : Studi Pada Masyarakat Jago Lombok Tengah

perempuan maka anak perempuan yang paling besar yang akan mengurus harta yang ditinggalkannya.

\section{Praktek Pembagian Harta Warisan pada Masyarakat Desa Jago}

Dari hasil temuan dilapangan bahwa praktek pembagian warisan di Desa Jago hampir sama sebagaimana umumnya pewarisan adat di daerah lain. Gambaran praktek pembagian warisan tidak terlepas dari tiga hal pokok, yaitu : ahli waris yang akan menerima harta warisan, harta peninggalan yang akan dibagi sebagai warisan, dan ketentuan yang akan diterima oleh ahli waris. Secara umum praktek pembagian harta warisan di Desa Jago dapat dibedakan menjadi dua, yaitu : Pembagian harta warisan terjadi pada saat pewaris masih hidup dan pembagian harta warisan setelah meninggal dunia.

Pembagian pada saat pewaris masih hidup, hal ini biasanya berkenaan dengan harta berupa rumah yang meliputi pekarangan dan seluruh isinya. Jika dalam sebuah keluarga lahir seorang anak laki-laki maka secara otomatis harta yang berupa rumah tadi secara turun-temurun akan menjadi haknya, walaupun hanya sebatas pengatasnamaan saja namun sudah dapat dipastikan nantinya akan jatuh kepada anak tertua laki-laki (sulung) tadi. Rumah merupakan sesuatu yang sangat vital dalam masyarakat adat Desa Jago, sehingga dianggap sebagai "jimat" yang penguasaan dan pemeliharaan diberikan kepada anak tertua. Apabila suatu hari nanti adik-adiknya ada yang terlantar atau putus hubungan dengan suaminya jika ia perempuan maka mereka berhak kembali ke rumah itu lagi, dan adat menetapkan rumah tidak boleh dijual, karena apabila dijual maka hasilnya harus dibagi kepada keluarga yang lain tidak lagi mutlak milik anak tertua tersebut. Orang Jago berkata "lamun tlang bale toaq tlang wah laim olek" hilang rumah tua hilang pula tempat kembali.

Kemudian pembagian harta warisan terjadi pada saat orang tua sudah meninggal dunia atau bisa juga orang tua sudah berumur lanjut dan anak tertua (sulung) sudah diaggap mampu untuk mengatur harta warisan. Biasanya hal ini yang berkaitan dengan harta yang berupa tanah dan sebagainya selain daripada rumah. Sebagaimana telah 
Syahdan | Pembagian Harta Warisan Dalam Tradisi Masyarakat Sasak : Studi Pada Masyarakat Jago Lombok Tengah

diuraikan sebelumnya bahwa masyarakat menganut sistem kewarisan mayorat, namun mayorat yang terbatas karena harta yang diberikan kepada anak tertua (sulung) tidak mutlak menjadi miliknya, ia berkewajiban dari harta tersebut memberikan kepada adikadiknya untuk bekal mereka nantinya.

Walaupun sistem kewarisan adat masyarakat desa Jago sudah banyak dimasuki pengaruh ajaran agama Islam, namun pada prakteknya sistem kewarisan adat masih sangat kuat dominasinya, hal ini terjadi karena beberapa faktor antara lain: (1) masyarakat sangat panatik terhadap tradisi nenek moyang nmereka, praktek tersebut merupakan warisan dari nenek moyang yang sudah mendarah daging. meskipun pada kenyataan masyarakatnya menganut agama Islam. (2) Keberadaan farầid kurang mendapat perhatian, barangkali karena sebagian besar tidak memahami bahkan mengenalnya disebabkan sulit dipelajari dan rumit sehingga lama-kelamaan keberadaannya punah. (3) Adanya anggapan bahwa anak bungsu selalu takluk dan patuh kepada anak yang tertua, mereka percaya bahwa anak tertualah yang berhak untuk mengatur semuanya menggantikan kedudukan kedua orang tuanya.

Masyarakat sangat tunduk kepada ketentuan adat sehingga tidak pernah didapati kasus yang mengenai pembagian warisan sampai ke pengadilan, kalau ada masalah kewarisan mereka menyerahkannya kepada para pemangku adat untuk diputuskan dalam musyawarah adat.

Di desa Jago tempo dulu menurut seorang informan M. Yusuf terdapat beberapa cara adat dalam memutuskan masalah warisan yang masuk ke pemangku adat antara lain yaitu: Jika ada keluarga yang mengalami masalah kewarisan mereka melakukan pengaduan/memasukkan perkara ke pemangku adat dengan membayar biaya yang disebut dengan galang silo kepada pemangku adat, biayanya ada yang 12 dan 24. Jika masalah tersebut telah diselesaikan dan menemukan jalan keluar maka diambil 10\% untuk pemangku adat. Namun cara penyelesaian seperti itu tidak berlaku lagi pada saat ini, jika sekarang ada masalah warisan maka pemangku adat cukup menentukan bagian masing-masing para ahli waris melalui mekanisme musyawarah adat juga. 
Syahdan | Pembagian Harta Warisan Dalam Tradisi Masyarakat Sasak : Studi Pada Masyarakat Jago Lombok Tengah

Dari uraian di atas mengenai praktek pembagian warisan di Desa Jago Kecamatan Praya dapat dipahami bahwa terdapat pembagian terhadap harta warisan kepada ahli waris lain selain dari pada anak tertua (sulung), walaupun pembagian tersebut hanya bisa dilakukan pada harta-harta tertentu, sedangkan besar bagian masing-masing ahli waris berbeda antara keluarga yang satu dengan yang lainnya, tergantung dari hasil musyawarah keluarga, dan juga melihat kondisi ahli waris dan harta warisan itu sendiri apakah masih memungkinkan untuk dibagi atau tidak.

\section{Pandangan Islam Terhadap Sistem Pembagian Harta Warisan Menurut Adat Desa Jago}

Keberadaan mengenai hukum adat yang ada Indonesia mengenal berbagai macam sistem kekeluargaan. Oleh karenanya, hukum adat Indonesia juga mengenal berbagai sistem kewarisan yaitu sistem individual, kolektif dan mayorat. Namun demikian sistem individual, kolektif ataupun mayorat dalam suatu hukum kewarisan tidak perlu langsung menunjuk kepada bentuk masyarakat di mana hukum kewarisan itu berlaku, sebab sistem kewarisan individual bukan saja dapat ditemui dalam masyarakat yang bilateral, tetapi juga dapat dijumpai dalam masyarakat yang patrilinial seperti di tanah Batak, malahan di tanah Batak itu di sana sini mungkin pula dijumpai sistem mayorat dan sistem kolektif terbatas, demikian juga sistem mayorat, selain dalam masyarakat yang patrilineal yang beralih-alih di tanah Semendo, dijumpai pula pada masyarakat bilateral orang Dayak di Kalimantan Barat, sedangkan sistem kolektif itu dalam batas-batas tertentu malahan dapat pula dijumpai dalam masyarakat yang bilateral seperti di Minahasa Sulawesi Utara (Hazairin, 1982: 15-16.)

Adapun dalam Islam hanya mengenal satu sistem kekeluargaan. Oleh karena itu, hukum Islam pun hanya mengenal satu macam sistem kewarisan yaitu individual. Sistem hukum kewarisan Islam adalah sistem kewarisan yang pelaksanaan dan penyelesaian harta warisan itu apabila pewaris itu benar-benar telah wafat. Jika ada yang wafat maka ada masalah waris. Jadi apabila ada seseorang yang meninggalkan harta kekayaan maka berarti ada harta warisan yang harus dibagi-bagikan kepada para ahli waris pria atau

Volume 4 Nomor 2 (2016) November $\mid \mathscr{P} \mathcal{A} \mathcal{L} \mathcal{A} \mathscr{P} \mathcal{A}:$ Jurnal Studi Keislaman 
Syahdan I Pembagian Harta Warisan Dalam Tradisi Masyarakat Sasak : Studi Pada Masyarakat Jago Lombok Tengah

wanita yang masih hidup dan juga memberikan bagian kepada anak-anak yatim dan fakir miskin. Di beberapa daerah di mana ajaran Islam telah mendarah daging sistem kewarisan Islam seperti ini berlaku. Sistem ini menurut Hazairin merupakan sistem individual bilateral (Hadikusuma, 2003: 31).

Dasar berlakunya sistem individual bilateral ialah al-Qur'an surat An-Nisa : ayat 7-8 dan surat An-Nisa' Ayat 33:

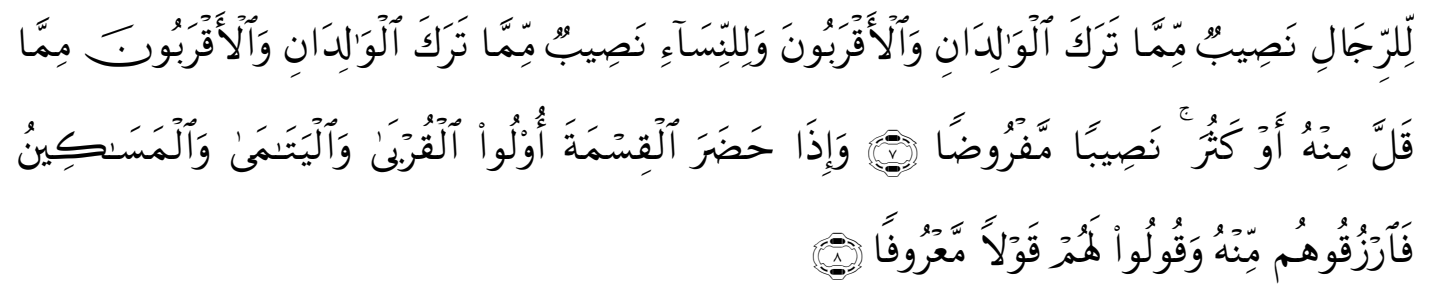

Artinya: Bagi orang laki-laki ada hak bagian dari harta peninggalan ibu-bapa dan kerabatnya, dan bagi orang wanita ada hak bagian (pula) dari harta peninggalan ibu-bapa dan kerabatnya, baik sedikit atau banyak menurut bahagian yang Telah ditetapkan.

Dan apabila sewaktu pembagian itu hadir kerabatanak yatim dan orang miskin, Maka berilah mereka dari harta itu (sekedarnya) dan ucapkanlah kepada mereka perkataan yang baik.

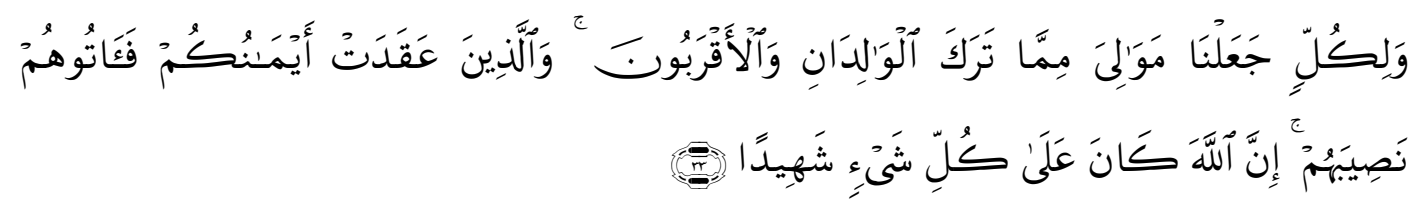

Artinya : Bagi tiap-tiap harta peninggalan dari harta yang ditinggalkan ibu bapak dan karib kerabat, kami jadikan pewaris-pewarisnya. dan (jika ada) orang-orang yang kamu Telah bersumpah setia dengan mereka, Maka berilah kepada mereka bahagiannya. Sesungguhnya Allah menyaksikan segala sesuatu (anNisa'33)

Sistem kewarisan mayorat yang ada dalam masyarakat adat Desa Jago, jika diamati maka pada prinsipnya sama dengan sistem kewarisan kolektif dimana setiap anggota ahli waris dari harta bersama mempunyai hak memakai dan menikmati harta bersama itu tanpa hak menguasai atau memilikinya secara perseorangan, hanya saja penerusan dan pengalihan hak penguasaan atas harta yang tidak terbagi-bagi itu dilimpahkan kepada 
Syahdan | Pembagian Harta Warisan Dalam Tradisi Masyarakat Sasak : Studi Pada Masyarakat Jago Lombok Tengah

anak tertua yang bertugas sebagai pemimpin rumah tangga atau kepala keluarga menggantikan kedudukan ayah atau ibu sebagai kepala keluarga.

Kelemahan dan kebaikan sistem kewarisan mayorat terletak pada kepemimpinan anak tertua dalam kedudukannya sebagai pengganti orang tua yang telah wafat dalam mengurus harta kekayaan dan memanfaatkannya guna kepentingan semua anggota keluarga yang ditinggalkan. Anak tertua yang penuh tanggung jawab akan dapat mempertahankan keutuhan dan kerukunan keluarga sampai semua ahli waris menjadi dewasa dan dapat berdiri sendiri mengatur rumah tangga sendiri. Tetapi anak tertua yang tidak bertanggung jawab, yang tidak dapat mengendalikan diri terhadap kebendaan, yang pemboros dan lain sebagainya jangankan akan dapat mengurus harta peninggalan dan saudara-saudaranya malahan sebaliknya ia yang diurus oleh anggota keluarga yang lain.

Sistem mayorat seringkali disalahtafsirkan tidak saja oleh orang yang tidak memahaminya, tetapi juga oleh pihak ahli waris anak tertua itu sendiri. Anak tertua sebagai pengganti orang tua yang telah meninggal bukanlah pemilik harta peninggalan secara perseorangan, ia hanya berkedudukan sebagai penguasa, sebagai pemegang mandat orang tua yang dibatasi oleh musyawarah keluarga, dibatasi oleh kewajiban mengurus anggota keluarga lain yang ditinggalkan, tidak semata-mata berdasarkan harta peninggalan tetapi juga berdasarkan asas tolong menolong oleh bersama untuk bersama. Jalan keluar dari kemungkinan munculnya perselisihan di antara para ahli waris dikemudian hari, pewaris dimasa hidupnya seringkali telah menunjukkan bagaimana cara mengatur harta kekayaan keluarganya. Jadi sebelum pewaris meninggal ia telah berpesan yang disampaikannya dengan terang kepada isteri dan anak-anaknya tentang bagaimana kedudukan harta kekayaannya kelak apabila ia telah wafat.

Sedangkan sistem kewarisan individual yang dikenal dalam Islam itu sejalan benar dengan pembawaan fitrah manusia, (Basyir, 2001:144). Sistem ini mengambil pendirian bahwa dengan matinya orang yang menjadi pewaris dengan sendirinya hak milik atas harta-hartanya itu berpindah kepada ahli waris-ahli warisnya, setelah berlalu beberapa waktu ahli waris itu membagi-bagikan harta antara mereka untuk dijadikan milik bersama semenjak matinya si pewaris menjadi milik perseorangan dengan jalan berbagi. Sistem ini 
Syahdan | Pembagian Harta Warisan Dalam Tradisi Masyarakat Sasak : Studi Pada Masyarakat Jago Lombok Tengah

menghendaki bahwa pada saat matinya si pewaris itu telah dapat diketahui dengan pasti siapa ahli waris-ahli waris itu, setidak-tidaknya telah wajib diketahui pada saat berbagi itu.

\section{PENUTUP}

1. Simpulan

Sistem kewarisan yang dipakai masayarakat Desa Jago kec.praya adalah sistem kewarisan mayorat laki-laki, dimana yang menjadi ahli waris utama adalah anak tertua laki-laki. Ia berkedudukan menggantikan kedua orang tuanya dalam mengatur harta warisan, mengatur adik-adiknya sampai mereka dewasa dan dapat berdiri sendiri.

Sistem dan Praktek pembagian harta warisan pada masyarakat Desa Jago kec.praya tidak sesuai dengan farâid. Namun berdasarkan tasâluh hal ini dibolehkan karena sesuai dengan tujuan pembentukan hukum Islam yaitu terwujudnya kemaslahatan ummat.

\section{Saran}

Tulisan ini adalah bagian kecil dari upaya pemecahan masalah, untuk itu dipandang perlu upaya-upaya seperti penyuluhan secara intensif terutama oleh para akademisi, penegak hukum dan para tuan guru, agar umat Islam Indonesia dalam segala hal merujuk kepada al-Qur'an dan Hadits Rasulullah SAW terutama yang berkenaan dengan kewarisan. Dan apa yang tersaji ini juga masih jauh dari sempurna, dan untuk pengkaji, peneliti selanjutnya diharapkan melakukan kajian lanjutan dengan melihat atau memandang dari sisi lain yang berkenaan dengan praktik pembagian harta warisan.

\section{E. DAFTAR PUSTAKA}

Abdullah, Abdul Gani, Pengantar Kompilasi Hukum Kewarisan Islam Dalam Tata Hukum Indonesia, Jakarta: Gema Insani Press, 1994.

Al-Bukhari, Abu 'Abdillah Muhammad Ibn Ibrâhîm al-Mughîrah, Sabih al-Bukhari, 8 Juz, Beirût: Dâr al-Fikr, 1981. 
Syahdan | Pembagian Harta Warisan Dalam Tradisi Masyarakat Sasak : Studi Pada Masyarakat Jago Lombok Tengah

Ali, Muhammad Daud, Hukum Islam Pengantar Ilmu Hukum dan Tata Hukum di Indonesia, Jakarta: PT Raja Grafindo Persada, 1993.

Anwar, Mohammad, Fara'id Hukum Waris Dalam Islam dan Masalah-Masalabnya, Surabaya: Al-Ikhlas, 1981.

Arikunto, Suharsimi, Prosedur Penelitian Suatu Pendekatan Praktek. Edisi Revisi V, Cetakan Keduabelas. Jakarta: PT Rineka Cipta, 2006.

Basyir, A.A. Hukum Waris Islam, cet. ke-14, Yogyakarta: UII Press, 2001.

Buku Data Monografi Tahun 2011 Desa Jago Kecamatan Praya Lombok Tengah

Daradjat, Zakiah, Ilmu Figh, Yogyakarta: PT Dana Bhakti Wakaf, 1995.

Departemen Agama RI, Al-Qur'an dan Terjemahnya, Surabaya: Mahkota, 1990.

Hazairin, Hukum Kewarisan Bilateral Menurut Al-Qur'an dan Hadis, Jakarta: Tintamas, 1982.

Hazairin, Pembaharuan Hukum Islam di Indonesia, Jakarta: UI Press, 1981.

Ramulyo, Idris, Perbandingan Pelaksanaan Hukum Kewarisan Islam dengan Kewarisan Menurut Kitab Undang-undang Hukum Perdata, Jakarta: Sinar Grafika, 1994.

Shabuniy, Muhammad Ali ash, Hukum Waris Islam, alih bahasa S. Syakur, Surabaya: AlIkhlas, 1995.

Shabuniy, Muhammad Ali ash, Pembagian Waris Menurut Islam, alih bahasa A.M.

Basalamah, Jakarta: Gema Insani Press, 1996.

Shiddieqy, T.M. Hasbi ash, Figh Mawaris, Hukum-bukum Waris dalam Syariat Islam, Jakarta: Bulan Bintang, 1974.

Syaikh Zainuddin Abdul Madjid al-Ampenan, Nabdlatuzzainiah, Toko Kita, 1996.

Yunus, Mahmud, Kamus Arab-Indonesia, Jakarta: PT Hidakarya Agung, 1989. 